\title{
How Much Does the State of the Economy Influence the Popularity of Austrian Parties? An Empirical Investigation
}

\author{
Friedrich Schneider ${ }^{1} \cdot$ Reinhard Neck $^{2}$ (D) \\ Michael M. Strugl ${ }^{1}$
}

(C) The Author(s) 2017. This article is published with open access at Springerlink.com

\begin{abstract}
We estimate popularity functions for the Austrian parties Austrian People's Party (ÖVP), Social Democrats (SPÖ) and Austrian Freedom party (FPÖ) between 1987 and 2010 (using annual data) as well as vote functions for the same Austrian parties in the 86 election districts in the national elections in 1999, 2002, 2006 and 2008. In most cases we find a statistically significant and theoretically predicted influence of three economic variables, namely the unemployment rate, inflation rate and growth rate of income, on both popularity and voting behavior. However, this influence is not robust and shows a tendency to decline over time.
\end{abstract}

Keywords Austrian popularity functions - Austrian vote functions · Economic influence on popularity and voting

JEL classification $\mathrm{D} 03 \cdot \mathrm{H} 11 \cdot \mathrm{P} 16$

\section{Introduction}

In the 1970s and 1980s there was a first wave of popularity and vote functions, which were estimated for almost all highly developed OECD countries. ${ }^{1}$ In the last 10 years these functions have enjoyed a certain revival, with studies for Germany (Kirchgässner

${ }^{1}$ Compare e.g. Lewis-Beck (1988), Nannestad and Paldam (1994), Paldam (2004), Kirchgässner (2009).

Reinhard Neck

Reinhard.neck@aau.at

1 Department of Economics, Johannes Kepler University Linz, Altenbergerstrasse 69, A-4040 Linz, Auhof, Austria

2 Department of Economics, Alpen-Adria-Universität Klagenfurt, A-9020 Klagenfurt, Austria 
2009) and Denmark (Paldam 2004) revealing new, and quite surprising, findings: The economic situation has much less influence on popularity than in the first wave of studies, where the majority of investigations showed a statistically highly significant and quantitatively important effect of the unemployment rate, the rate of inflation and the growth rate of income on popularity or on the outcomes of elections. In this paper an attempt is made to undertake an empirical investigation exploring the extent to which the economic situation influences the popularity of Austrian parties. Additionally, our study is a first attempt to estimate the influence of the economic situation on outcomes in the 86 election districts in the federal elections in 1999, 2002, 2006 and 2008. We find that the influence of the economic situation is mixed, becoming less important the more recent the elections are.

\section{Theoretical Considerations}

In this section, we provide some theoretical considerations and a short literature review. ${ }^{2}$ Voting and popularity models analyze the relationship between economic and political variables and support for a country's government. According to Nannestad and Paldam (1994) and Paldam (2004), about 300 papers on vote and popularity functions were written from around 1970 onwards. Most of this research is empirical in nature, and one general finding is that, according to Downs' theory, selfish politicians' and voters' behavior can be reduced to the operational idea known as the responsibility hypothesis, meaning that voters hold governments responsible for the past performance of the economy. This hypothesis predicts that if the economy is doing well, voters will approve of this and the popularity or election outcomes of the governing party (or parties) will increase. Likewise, if the economy is in bad shape, the popularity or election outcomes of these parties will sink.

Most authors choose a linear functional relationship to model the vote and popularity function, and in most cases three economic variables, namely the unemployment rate, inflation rate and growth rate of personal disposable income, are used. This is also the case for this paper; hence, we model the popularity and vote function as follows:

$\begin{aligned} & \{\text { POP-Austria Party-A or Election } \\ & \text { Outcome Party-A }\}\end{aligned}=F \quad \begin{aligned} & \text { \{unemployment rate } U E Q, \text { rate of inflation } R I, \text { growth } \\ & \text { rate of personal income } R P I, \text { and other variables }\}\end{aligned}$

The theoretically expected signs are $U E Q<0, R I<0$ and $R P I>0 .^{3}$

The facts about the empirical results of vote and popularity functions over the period 1970 to 1990 can be summarized as follows: Most of the empirical findings derive from estimates built upon the responsibility hypothesis. This hypothesis offers a simple and reduced link between the economy and the voter. A second important finding is that the vote and popularity functions do not produce very stable results. Third, it is difficult to

\footnotetext{
$\overline{2}$ There is a huge body of literature on the theory of voting which will not be discussed in this paper. We will only provide some theoretical considerations and the latest empirical results. For example, compare the excellent surveys by Paldam $(1981,2004)$ and Nannestad and Paldam (1994). See also the earlier survey by Schneider and Frey (1988).

${ }^{3}$ In this paper, we do not discuss whether, from an economic or public choice standpoint, it is rational to vote at all and whether voters act as rational agents with a forward-looking perspective (compare Paldam (2004)).
} 
compare the results from the various authors and for different countries because almost every author has his or her own specifications.

One more recent empirical study was undertaken by Kirchgässner (2009), who argued that increasing unemployment and inflation had mostly had a negative impact on a government's popularity. This was true for Germany as well. These variables had the predicted negative influence on the popularity of the governments of Adenauer, Erhard, Brandt, Schmidt and Kohl and were statistically highly significant. However, this result does not hold for Schröder's government (1998-2005). Neither unemployment nor inflation had a statistically significant influence on its popularity. Kirchgässner argues that the missing impact of unemployment might be due to statistical reasons, namely the short observation period and low variance in the explanatory variables. As for inflation, the voters might have realized that they could no longer hold the government responsible for this phenomenon as the European Central Bank (ECB) had been in charge of monetary policy in Europe since 1999. Although Kirchgässner found no significant influence of the macroeconomic variables on the popularity of Schröder's government, he believed that it was much too early to draw the general conclusion that voters do not hold governments responsible for economic developments because more and better data would be needed to undertake further investigations to confirm such an assumption.

The only studies dealing with the Austrian situation are those by Neck (1979, 1988, 1996), Hofreither (1988) and Neck and Karbuz (1995, 1997). Their main results are as follows: the rate of unemployment, the growth rate of disposable income and the rate of inflation were identified as economic determinants of voters' evaluation of political parties. They found evidence for a structural break in the popularity functions related to the change from a one-party or small coalition government to a "grand" coalition (a coalition of the big parties SPÖ and ÖVP). For a one-party government or a small coalition, the predictions of the responsibility hypothesis were confirmed for the popularity functions. However, these results were not very stable. In some cases they had the expected coefficient and sign predicted by theory, while in other cases they did not. In the next section, the econometric results of the popularity and vote functions are presented.

\section{Empirical Results}

\section{Some Remarks About the Austrian Political System}

Austria is a representative democracy in which parliamentary elections took place (at least) every four years until 2008 and then (at least) every five years. At the federal level, there is a clear distinction between the opposition and the government, and in most periods the government was formed either by a "grand" coalition between the two biggest parties, the SPÖ and the ÖVP, or by a coalition consisting of one big party with a "minor" partner, the FPÖ. A single party has not had a majority in parliament since the early 1980 s and even before then it was quite rare. 


\section{Results of the Popularity Function in Austria}

First, the estimation results for the popularity functions are presented for the Austrian parties at the federal level. Due to data restrictions and the switching of the two big parties between government and opposition, we only investigate these functions over the time period 1987 to 2010 , adding up to 24 annual observations. Here we have the situation that only the People's Party $(V P)$ was in government continuously, either as a junior partner or as a senior one. As a junior partner of the Social Democrats $(S P)$, they governed from 1987 to 1999 and from 2007 to 2010. As a senior partner, the People's Party governed together with the Freedom Party $(F P)$ from 2000 to 2006. For the Social Democrats and the Freedom Party, the empirical investigation is more difficult because they both switched between government and opposition within this period, but at least the People's Party was in power all of the time.

In Table 1, the estimation results of the popularity functions of the Austrian parties at the federal level are shown over the period 1987-2010. ${ }^{4}$ Taking into consideration that the People's Party was the dominating force from 2000 to 2006 and that the chancellor came from this party, we model this with a dummy variable $D Y V(=1$ over the period 2000 to 2006 , otherwise $=0$ ).

In the econometric results of the People's Party, the chancellor dummy variable has a statistically significant influence, raising the popularity of the People's Party by 3.2 percentage points. The unemployment rate, inflation rate and growth rate of disposable income have the predicted signs, but only the unemployment variable is statistically significant, and only if the income variable is omitted. If the rate of unemployment rises by one percentage point, the popularity of the People's Party drops by 0.81 percentage points. For the Social Democratic Party and the Freedom Party, the economic variables have no statistically significant influence and the popularity of the Freedom Party incurs a severe drop when taking the chancellor dummy variable for the People's Party into account. The Freedom Party loses 6.1 percentage points over this time period, and this influence is statistically highly significant. Otherwise, none of the economic variables is statistically significant, which is not surprising as these parties were partly in government and partly in opposition in the period concerned.

Due to the switching of the SPÖ and the FPÖ between government and opposition, an attempt was made to split the economic variables into two periods, one from 1987 to 1999 and 2007 to 2010 and the other from 2000 to 2006. This reflects the fact that the economic variables have a different influence when a party is in opposition compared to the situation when it is in government. The results are shown in Table 2, with all three economic variables in part 1 and with only inflation and unemployment as explanatory variables in part 2 .

Considering Table 2 part 1 , at first glance the results are better than in Table 1 but are still quite mixed. If we first turn to the People's Party, we realize that the estimated coefficients for the unemployment rate have the negative signs as predicted theoretically but are only statistically significant for the periods 1987-1999 and 2007-2010. If

\footnotetext{
${ }^{4}$ To estimate the popularity functions using time series data, we use the generalized least squares (GLS) method with a Prais-Winsten transformation. This transformation controls for serial correlation and accounts for the first observation, which would otherwise be lost. In doing so, we obtain efficient results for an autoregressive process of order one. This estimator is also known as the Yule-Walker estimator. All regressions are iterated multiple times and converge according to a default threshold (Sargan 1964).
} 


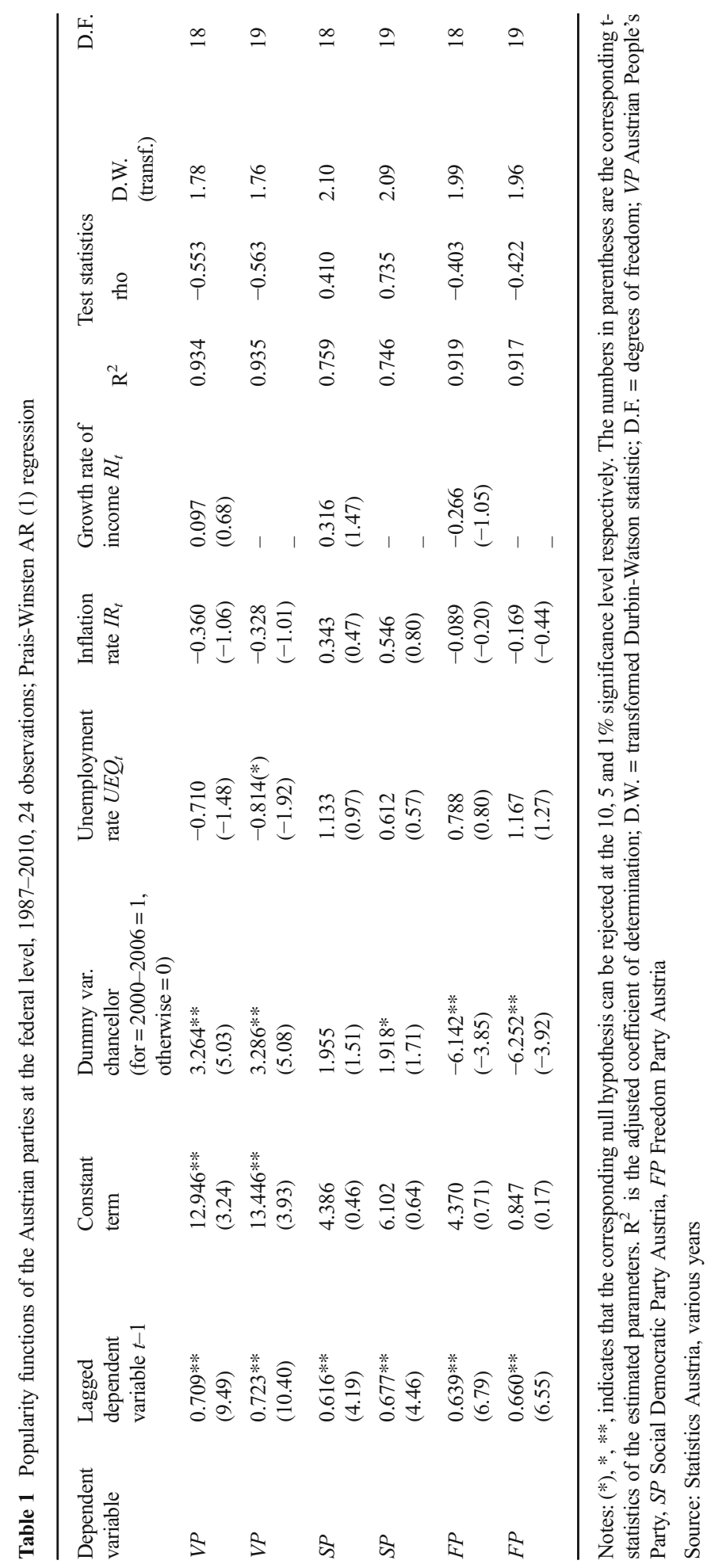


the rate of unemployment rose by one percentage point, the People's Party lost 1.66 percentage points of popularity. We also obtain the predicted negative sign for the inflation rate, but it is statistically significant only for the period 2000-2006, with a quantitatively important coefficient. If inflation rose by one percentage point, the People's Party lost 2.72 percentage points in popularity. The growth rate of disposable income has no statistically significant influence.

Considering the Social Democratic Party, the split of the three economic variables yields the signs predicted by the theory. When the Social Democrats were in opposition over the period 2000-2006, an increase in unemployment helped them to gain popularity. If the unemployment rate rose by one percentage point, the Social Democratic Party gained 1.7 to 2.2 percentage points. The growth rate of disposable income also has the predicted negative sign and is statistically highly significant for the period when this party was in opposition. If the growth rate of income rose by one percentage point during the period 20002006, the Social Democratic Party lost between one and 0.75 percentage points. For the second period (1987 to 1999 and 2007 to 2010), in which the Social Democrats were in government, if the growth rate of disposable income increased by one percentage point, the Social Democratic Party gained 0.53 percentage points. Considering the Freedom Party, which was in government from 20002006, we get a positive influence of the inflation rate, contrary to theoretical predictions. None of the other coefficients is statistically significant. Neither is the chancellor variable statistically significant when the economic variables are split.

Now let us turn to the results of the popularity function at the federal level using the unemployment rate and the inflation rate as explanatory variables only, as shown in Table 2, part 2. Here we do not find different results for the People's Party and the Social Democratic Party. However, the Freedom Party has the expected negative influence of the unemployment rate when this party was in government in 20002006 and a positive influence of the unemployment rate when this party was in opposition. During its time in government, the Freedom Party lost 4.8 percentage points if the rate of unemployment rose by one percentage point, and it gained $2.7 \%$ in the same situation during its time in opposition. The Freedom Party also gained from rising inflation, namely between 1.7 and 4.6 percentage points, a result that is not in accordance with theoretical predictions as the Freedom Party was in government during this time. Summarizing the results of Tables 1 and 2, part 1 and part 2, we gain the overall impression that economic variables have some influence on the popularity of the Austrian parties at the federal level, but in general the influence is quite weak and not very robust.

\section{Results of the Vote Function}

The influence of the state of the economy on the election outcome of single parties was investigated for the national elections in 1999, 2002, 2006 and 2008 in the 86 election districts at the federal level. The People's Party was in government for all four elections and was the dominant party (with the federal chancellor) for the elections in 2002 and 2006. In the two remaining elections (1999 and 2008), the Social Democrats were the dominant government party. In our empirical study, the four elections are investigated separately for the People's Party, the Social Democratic Party and the Freedom Party. 


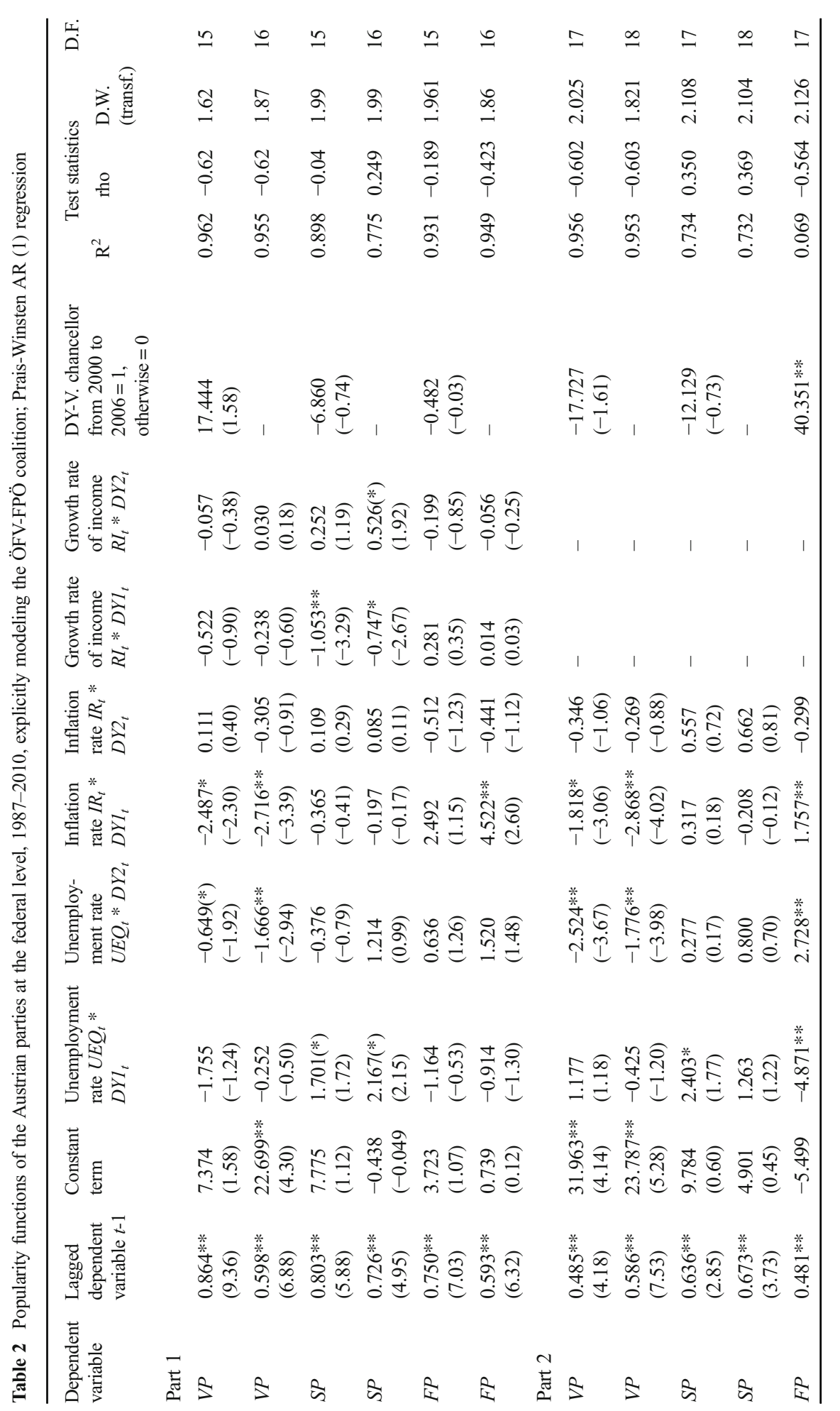




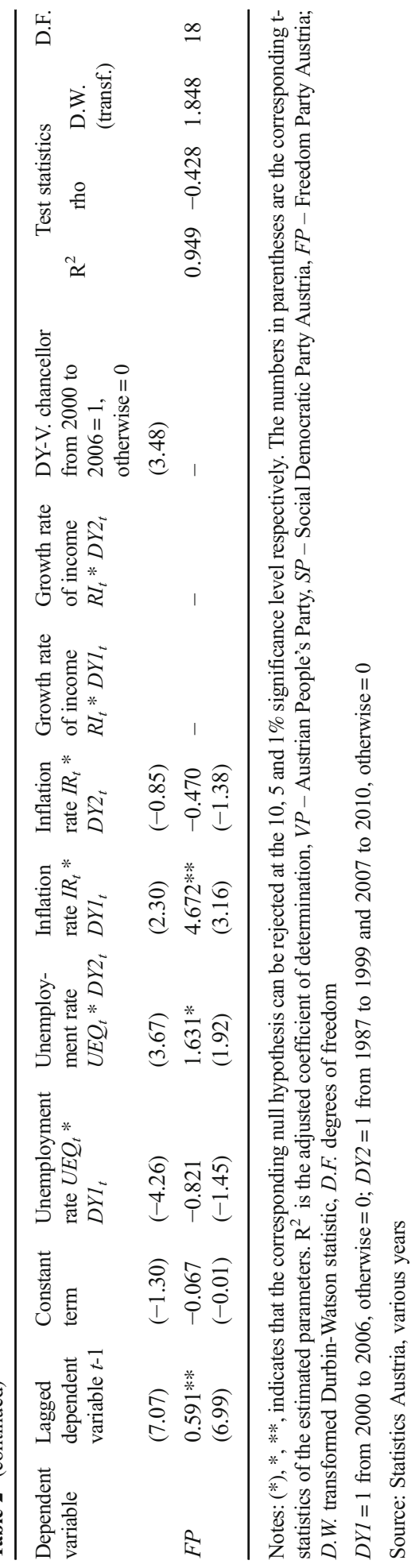


In Table 3, the results of the elections are presented for the People's Party for these four elections. Consider first the results presented in the respective first line (without the lagged endogenous variable). With one exception the two economic variables have the predicted signs, but their statistical significance varies over the four elections. If we first turn to the unemployment rate, it had no statistically significant influence on the 1999 elections for the People's Party but a statistically significant influence on the results of the remaining three elections (2002, 2006 and 2008). If the rate of unemployment increased by one percentage point, the People's Party lost 1.2, 1.4 and 1.0 percentage points in the elections in 2002, 2006 and 2008 respectively. If we turn to the growth rate of disposable income, we have a statistically significant influence in all four cases, but for the last election in 2008 the estimate has the "wrong" (not theoretically expected, negative) sign, the People's Party losing 0.7 percentage points on an increase in the rate of income by one percentage point. For the remaining three elections (1999, 2002 and 2006), the People's Party gained 3.6, 4.3 and 1.6 percentage points respectively, if the growth rate of income rose by one percentage point.

In Table 4, the election function results are shown for the Social Democratic Party. As the Social Democrats were in opposition in the 2002 and 2006 elections and in government in 1999 and 2008, we have to consider this when interpreting these results. For the 2002 election, we get the expected result: if unemployment rose by one

Table 3 Election functions for the Austrian People's Party in 1999, 2002, 2006, 2008: Cross-sectional regression

\begin{tabular}{|c|c|c|c|c|c|c|}
\hline $\begin{array}{l}\text { Dependent } \\
\text { variable }\end{array}$ & $\begin{array}{l}\text { Lagged }^{\text {a }} \text { dependent } \\
\text { variable } t-1\end{array}$ & $\begin{array}{l}\text { Constant } \\
\text { term }\end{array}$ & $\begin{array}{l}\text { Unemployment } \\
\text { rate } U E Q_{t}\end{array}$ & $\begin{array}{l}\text { Growth rate of } \\
\text { income } R I_{t}\end{array}$ & $\begin{array}{l}\text { Test } \\
\text { statistic } \\
\mathrm{R}^{2}\end{array}$ & D.F. \\
\hline \multirow[t]{2}{*}{$V P 1999$} & - & $\begin{array}{l}28.099 * * \\
(5.55)\end{array}$ & $\begin{array}{l}-0.906 \\
(-1.45)\end{array}$ & $\begin{array}{l}3.579 * \\
(2.12)\end{array}$ & 0.102 & 84 \\
\hline & $\begin{array}{l}0.820 * * \\
(7.98)\end{array}$ & $\begin{array}{l}5.665 \\
(1.20)\end{array}$ & $\begin{array}{l}-0.682(*) \\
(-1.78)\end{array}$ & $\begin{array}{l}1.302 * \\
(1.99)\end{array}$ & 0.818 & 81 \\
\hline \multirow[t]{2}{*}{$V P 2002$} & - & $\begin{array}{l}43.801 * * \\
(9.34)\end{array}$ & $\begin{array}{l}-1.203^{* *} \\
(-2.00)\end{array}$ & $\begin{array}{l}4.348 * * \\
(3.20)\end{array}$ & 0.133 & 84 \\
\hline & $\begin{array}{l}1.026 * * \\
(31.36)\end{array}$ & $\begin{array}{l}13.507 * \\
(7.48)\end{array}$ & $\begin{array}{l}-0.079 \\
(-0.40)\end{array}$ & $\begin{array}{l}0.754 * \\
(2.00)\end{array}$ & 0.918 & 81 \\
\hline \multirow[t]{2}{*}{$V P 2006$} & - & $\begin{array}{l}40.550 * * \\
(10.72)\end{array}$ & $\begin{array}{l}-1.373^{*} \\
(-2.24)\end{array}$ & $\begin{array}{l}1.670 * * \\
(4.85)\end{array}$ & 0.232 & 84 \\
\hline & $\begin{array}{l}0.964 * * \\
(48.30)\end{array}$ & $\begin{array}{l}-6.106^{* * *} \\
(-5.15)\end{array}$ & $\begin{array}{l}(-0.123) \\
(-1.13)\end{array}$ & $\begin{array}{l}0.206 * * \\
(3.91)\end{array}$ & 0.984 & 81 \\
\hline \multirow[t]{2}{*}{$V P 2008$} & - & $\begin{array}{l}35.054 \\
(10.73)\end{array}$ & $\begin{array}{l}-0.970\left(^{*}\right) \\
(-1.67)\end{array}$ & $\begin{array}{l}-0.677 * * \\
(-3.87)\end{array}$ & 0.162 & 84 \\
\hline & $\begin{array}{l}0.858 * * \\
(29.01)\end{array}$ & $\begin{array}{l}-3.767^{*} \\
(-2.20)\end{array}$ & $\begin{array}{l}0.011 \\
(0.06)\end{array}$ & $\begin{array}{l}0.129 * * \\
(3.01)\end{array}$ & 0.942 & 81 \\
\hline
\end{tabular}

Notes: $(*), * * *$, indicates that the corresponding null hypothesis can be rejected at the 10,5 and $1 \%$ significance level respectively. The numbers in parentheses are the corresponding t-statistics of the estimated parameters. $\mathrm{R}^{2}$ is the adjusted coefficient of determination. D.F. = degrees of freedom; $V P$ - Austrian People's Party. The People's Party was in government over all four elections

Source: Statistics Austria, various years

${ }^{a}$ Result at the last election 
Table 4 Election functions for the Social Democrats in 1999, 2002, 2006, 2008: Cross-sectional regression

\begin{tabular}{llllll}
\hline $\begin{array}{l}\text { Dependent } \\
\text { variable }\end{array}$ & $\begin{array}{l}\text { Constant } \\
\text { term }\end{array}$ & $\begin{array}{l}\text { Unemployment } \\
\text { rate } U E Q_{t}\end{array}$ & $\begin{array}{l}\text { Growth } \\
\text { rate } \\
\text { of income } \\
\mathrm{RI}_{\mathrm{t}}\end{array}$ & $\begin{array}{l}\text { Test } \\
\text { statistic } \\
\mathrm{R}^{2}\end{array}$ & D.F. \\
$S P$ 1999 & $\begin{array}{l}30.896^{* *} \\
(9.10)\end{array}$ & $\begin{array}{l}1.163^{* *} \\
(2.24)\end{array}$ & $\begin{array}{l}-2.652^{* *} \\
(-2.55)\end{array}$ & 0.115 & 84 \\
$S P 2002$ & $32.525^{* *}$ & $1.580^{* *}$ & $-3.262^{* *}$ & 0.139 & 84 \\
$S P 2006$ & $(7.60)$ & $(2.88)$ & $(-2.63)$ & & 84 \\
$S P 2008$ & $30.828^{* *}$ & 0.787 & -0.410 & 0.029 & 84 \\
& $(8.10)$ & $(1.28)$ & $(-1.18)$ & & \\
& 26.404 & 0.267 & 0.264 & 0.028 & \\
\hline
\end{tabular}

Notes: $(*), *, * *$, indicates that the corresponding null hypothesis can be rejected at the 10,5 and $1 \%$ significance level respectively. The numbers in parentheses are the corresponding t-statistics of the estimated parameters. $\mathrm{R}^{2}$ is the adjusted coefficient of determination; D.F. = degrees of freedom; $S P-$ Social Democratic Party Austria. The Social Democratic Party was in government before the 1999 and 2008 elections; for the elections in 2002 and 2006 they were in opposition

Source: Statistics Austria, various years

percentage point, the election outcome of the Social Democrats increased by 1.6 percentage points. If the growth rate of disposable income increased by 1 percentage point, the Social Democrats in opposition lost 3.3 percentage points. However, the same influence is indicated for 1999. Here we do not get the theoretically expected signs, as the Social Democrats were in government and even had the federal chancellor. For the elections in 2006 and 2008, the economic variables had no statistically significant influence.

Finally, if we turn to the election results of the Freedom Party (Table 5), which was in power in the elections in 2002 and 2006, we find a statistically significant and theoretically expected sign for the unemployment variable for the elections in 2006 and 2008. If the rate of unemployment rose by one percentage point, the Freedom Party lost 0.48 percentage points in 2006 . However, the growth rate of income has the "wrong" (theoretically not expected) negative sign, meaning that if income rose by one percentage point, the Freedom Party lost 0.16 percentage points. For the elections in 2008 the unemployment rate had a statistically significant negative influence. This is again the "wrong" sign, meaning that if unemployment rose by one percentage point, the Freedom Party (in opposition) lost 0.1 percentage points.

Summarizing the results of the separate estimations of the four election functions for the three parties, we must admit that only considering the influence of economic variables may lead to a misspecification of the estimated equations. In Tables 3 and 5, a first attempt is made to tackle this issue by also considering the influence of the previous election (presented in the respective second line). If we first start with the People's Party, the results are shown in Table 3. The lagged endogenous variable (outcome of the last election) has a statistically highly significant positive influence on the result of subsequent elections in 1999, 2002, 2006 and 2008. If we turn to the two economic variables (unemployment and income growth), we discover that unemployment has a statistically significant influence with the theoretically predicted negative sign only for the election in 1999. If the unemployment rate rose by one 
Table 5 Election functions for the Freedom Party in 1999, 2002, 2006, 2008: Cross-sectional regression

\begin{tabular}{|c|c|c|c|c|c|c|}
\hline $\begin{array}{l}\text { Dependent } \\
\text { variable }\end{array}$ & $\begin{array}{l}\text { Lagged }^{\mathrm{a}} \\
\text { dependent } \\
\text { variable } t \text {-1 }\end{array}$ & $\begin{array}{l}\text { Constant } \\
\text { term }\end{array}$ & $\begin{array}{l}\text { Unemployment } \\
\text { rate } U E Q_{t}\end{array}$ & $\begin{array}{l}\text { Growth } \\
\text { rate } \\
\text { of income } \\
R I_{t}\end{array}$ & $\begin{array}{l}\text { Test } \\
\text { statistic } \\
\mathrm{R}^{2}\end{array}$ & D.F. \\
\hline \multirow[t]{2}{*}{ FP 1999} & - & $\begin{array}{l}25.653^{* * *} \\
(9.26)\end{array}$ & $\begin{array}{l}0.373 \\
(0.98)\end{array}$ & $\begin{array}{l}-0.278 \\
(-0.29)\end{array}$ & 0.022 & 84 \\
\hline & $\begin{array}{l}0.924 * * \\
(26.64)\end{array}$ & $\begin{array}{l}6.831 * * \\
(4.45)\end{array}$ & $\begin{array}{l}0.270 * \\
(1.97)\end{array}$ & $\begin{array}{l}-0.757(*) \\
(-1.68)\end{array}$ & 0.859 & 82 \\
\hline \multirow[t]{2}{*}{ FP 2002} & - & $\begin{array}{l}9.018 * * \\
(3.50)\end{array}$ & $\begin{array}{l}0.418 \\
(1.27)\end{array}$ & $\begin{array}{l}-0.484 \\
(-0.65)\end{array}$ & 0.022 & 84 \\
\hline & $\begin{array}{l}0.809 * * \\
(13.31)\end{array}$ & $\begin{array}{l}-11.977 \\
(-5.88)\end{array}$ & $\begin{array}{l}0.169 \\
(1.08)\end{array}$ & $\begin{array}{l}-0.278 \\
(-1.10)\end{array}$ & 0.811 & 82 \\
\hline \multirow[t]{2}{*}{ FP 2006} & - & $\begin{array}{l}13.817 * * \\
(14.60)\end{array}$ & $\begin{array}{l}-0.482 * * \\
(-3.14)\end{array}$ & $\begin{array}{l}-0.166(*) \\
(-1.93)\end{array}$ & 0.169 & 84 \\
\hline & $\begin{array}{l}0.042 \\
(0.79)\end{array}$ & $\begin{array}{l}13.525 * * \\
(14.32)\end{array}$ & $\begin{array}{l}-0.504 * * \\
(-3.02)\end{array}$ & $\begin{array}{l}-0.170(*) \\
(-1.77)\end{array}$ & 0.177 & 82 \\
\hline \multirow[t]{2}{*}{ FP 2008} & - & $\begin{array}{l}22.047 * * \\
(15.51)\end{array}$ & $\begin{array}{l}-0.997 * * \\
(-3.96)\end{array}$ & $\begin{array}{l}0.002 \\
(0.03)\end{array}$ & 0.164 & 84 \\
\hline & $\begin{array}{l}1.056^{* * *} \\
(9.47)\end{array}$ & $\begin{array}{l}7.907 \\
(4.97)\end{array}$ & $\begin{array}{l}-0.384(*) \\
(-1.90)\end{array}$ & $\begin{array}{l}-0.630 \\
(-0.89)\end{array}$ & 0.556 & 82 \\
\hline
\end{tabular}

Notes: $(*), * * *$, indicates that the corresponding null hypothesis can be rejected at the 10,5 and $1 \%$ significance level respectively. The numbers in parentheses are the corresponding t-statistics of the estimated parameters. $\mathrm{R}^{2}$ is the adjusted coefficient of determination; D.F. $=$ degrees of freedom; $F P-$ Freedom Party Austria. The Freedom Party was in government in 2002 and 2006 and in opposition in 1999 and 2008

Source: Statistics Austria, various years

${ }^{a}$ Result at the last election

percentage point, the People's Party lost 0.68 percentage points in 1999. Likewise the growth rate of disposable income has a statistically highly significant positive influence (as theoretically expected) on all four election outcomes: if the growth rate of disposable income rose by one percentage point, the People's Party gained 1.3, 0.76, 0.2 and 0.13 percentage points in the elections in 1999, 2002, 2006 and 2008 respectively. It is interesting to note that the quantitative influence of the income growth variable shrinks considerably over these four elections from 1.3 percentage points in 1999 to only 0.13 percentage points in the election in 2008 , but it is statistically highly significant in all four elections.

Regarding the empirical results of the four elections for the Social Democrats (available from the authors), we remind the reader that they were in opposition in 2002 and 2006 and in power in 1999 and 2008. Only for the two elections in 2002 and 2006 do we find a statistically significant influence of the independent variables, namely for unemployment in 2002 and for the growth rate of disposable income in 2006. In both cases, the economic variables have the "wrong" signs, i.e. negative for unemployment and positive for inflation. One would expect the opposite effect for an opposition party.

In Table 5, the estimations are presented for the election results of the Freedom Party. Again, note that the Freedom Party was in opposition in the elections in 1999 and 2008 and in government in the elections in 2002 and 2006. The two economic variables have the theoretically predicted signs (for an opposition party) in the 1999 election: a positive 
influence for unemployment and a negative one for the growth rate of income. If unemployment rose by one percentage point, the Freedom Party gained three percentage points. If income rose by one percentage point, they lost 0.76 percentage points. In the election in 2006, when the Freedom Party was in government, the two economic variables again are statistically significant. If unemployment rose by one percentage point, the party lost 0.5 percentage points, as predicted theoretically, but if income rose by one percentage point they lost 0.2 percentage points, which is not the predicted sign. In the other cases, the economic variables have no statistically significant influence. To summarize: If we include the lagged dependent variable (the last election result) in order to take account of the ceteris paribus condition, the economic variables have a statistically more significant influence with the predicted signs in most cases.

Finally in Tables 6 and 7 an attempt is made to undertake panel estimations over all four elections. Of course, this is only possible for the People's Party as this was the only one which was in government all of the time. In Table 6, a panel estimation random effects (RE) method is shown including election dummies for 2002, 2006 and 2008. ${ }^{5}$

If we consider the results in Table 6, we notice that the election dummy variables for 2002 and 2006 have a statistically significant influence. The two economic variables have the predicted signs and are statistically highly significant. If the unemployment rate rose by one percentage point, the election outcome of the People's Party decreased by 0.46 percentage points. If the growth rate of disposable income increased by one percentage point, the election outcome of the People's Party increased by 0.15 percentage points. These influences are quantitatively not important, but they are statistically highly significant.

In Table 7, the results of a panel estimation using the lagged dependent variable (last election outcome) and applying a FGLS ${ }^{6}$ regression are shown. In comparison to Table 6 , note that the growth rate of disposable income still has a statistically highly significant influence which has increased in terms of quantitative importance, but the unemployment variable is not statistically significant. If the growth rate of disposable income increased by one percentage point, the election outcome of the People's Party increased by 0.39 to 0.47 percentage points. This is a much larger influence when compared to the result in Table 6.

\section{Summary and Conclusions}

Summarizing the results of our paper, we find:

(1) With respect to the popularity functions of the Austrian parties at the federal level over the period 1987-2010, we have to take into account that only the People's Party was in government all the time while the other parties examined switched

\footnotetext{
${ }^{5}$ When the random effects estimation method is used, it is sometimes argued that this method generates a quasi-differenced estimator. This is due to the fact that the generalized least squares (GSL) regression delivering this random effect estimator within panel data is equivalent to ordinary least squares (OLS) using quasi-demeaned data. In other words, from each estimator's average, we subtract a fraction $\theta$. Therefore, $\theta$ needs to be calculated, which in turn requires estimates of the within and between variances. In general, if assumptions are met, RE is efficient and consistent. In our model, the GLS estimator is the weighted average of the between and within variance.

${ }^{6}$ As it is very difficult to undertake a panel estimation using a lagged dependent variable, one possible tool is the feasible generalized least squares (FGLS), which explicitly computes an individual covariance matrix for GLS each time instead of using an assumed one.
} 
Table 6 Election function of the Austrian People's Party in the elections in 1999, 2002, 2006, 2008, Panelestimation random effects, GLS estimation procedure; Election dummies DY2002, DY2006 and DY2008

\begin{tabular}{|c|c|c|c|c|c|c|c|c|c|c|}
\hline Dependent & Constant & DY2002 & DY2006 & DY2008 & Unemployment & Growth & \multicolumn{3}{|c|}{ Test statistics } & D.F. \\
\hline variable & term & & & & rate $U E Q_{t}$ & $\begin{array}{l}\text { rate of } \\
\text { income } \\
R I_{t}\end{array}$ & $\mathrm{R}^{2}$ & rho & $\mathrm{chi}^{2}$ & \\
\hline$V P$ & $\begin{array}{l}33.351 * * \\
(25.21)\end{array}$ & $\begin{array}{l}15.61 * * \\
(49.21)\end{array}$ & $\begin{array}{l}7.57 * * \\
(24.40)\end{array}$ & $\begin{array}{l}-1.372 \\
(-5.74)\end{array}$ & $\begin{array}{l}-0.458 * \\
(-2.50)\end{array}$ & $\begin{array}{l}0.148 * * \\
(4.47)\end{array}$ & 0.358 & 0.965 & 5297.0 & 85 \\
\hline
\end{tabular}

Notes: $(*), * * *$, indicates that the corresponding null hypothesis can be rejected at the 10,5 and $1 \%$ significance level respectively. The numbers in parentheses are the corresponding t-statistics of the estimated parameters. $\mathrm{R}^{2}$ is the adjusted coefficient of determination; D.F. $=$ degrees of freedom

Source: Own calculations based on data from Statistics Austria, various years

from government to opposition and vice versa. If we consider the period where the People's Party dominated and the Freedom Party was the "junior" partner (2000 to 2006), only the inflation rate had a statistically significant influence and the theoretically predicted negative sign. For the Social Democrats, in opposition at this point, the coefficient of the unemployment rate had the predicted positive sign. It is statistically significant, as is the growth rate of disposable income, which also has the theoretically predicted negative sign. For the junior coalition party, the Freedom Party, we now get a statistically significant influence except for the coefficient for the inflation rate, which has the wrong (positive) sign.

Considering the second period, when Austria had a "grand coalition" involving the Social Democratic Party and the People's Party, unemployment had a negative influence as predicted theoretically which is statistically significant. We also find for the Social Democrats, now back in government, that the growth rate of income has the expected positive sign and is statistically significant. In general these results show that the economic situation has some influence on the popularity of the Austrian parties, but these results are mixed and are not stable.

(2) Turning to the influence of the economic situation on the election outcomes for the Austrian parties in 1999, 2002, 2006 and 2008, we find for the People's Party,

Table 7 Election functions of the Austrian People's Party in the elections in 1999, 2002, 2006 and 2008; with the lagged dependent variable; cross-sectional time series feasible generalized least squares estimation

\begin{tabular}{|c|c|c|c|c|c|c|}
\hline $\begin{array}{l}\text { Dependent } \\
\text { variable }\end{array}$ & $\begin{array}{l}\text { Lagged } \\
\text { dependent } \\
\text { variable } t \text {-1 }\end{array}$ & $\begin{array}{l}\text { Constant } \\
\text { term }\end{array}$ & $\begin{array}{l}\text { Unemployment } \\
\text { rate } U E Q\end{array}$ & $\begin{array}{l}\text { Growth rate } \\
\text { of income } R I\end{array}$ & $\begin{array}{l}\text { Test statistics } \\
\mathrm{chi}^{2}\end{array}$ & D.F. \\
\hline$V P$ & $\begin{array}{l}0.601 * * \\
(13.74)\end{array}$ & $\begin{array}{l}11.822 * * \\
(4.57)\end{array}$ & $\begin{array}{l}0.242 \\
(0.81)\end{array}$ & $\begin{array}{l}0.387^{*} \\
(2.46)\end{array}$ & 197.6 & 85 \\
\hline $\begin{array}{l}V P \\
\text { Common AR (1) } \\
\text { coefficient }-0.119\end{array}$ & $\begin{array}{l}0.648 * \\
(15.74)\end{array}$ & $\begin{array}{l}10.385^{* *} \\
(2.425)\end{array}$ & $\begin{array}{l}0.206 \\
(0.75)\end{array}$ & $\begin{array}{l}0.472^{*} \\
(2.89)\end{array}$ & 259.3 & 85 \\
\hline
\end{tabular}

Notes: $(*), *, * *$, indicates that the corresponding null hypothesis can be rejected at the 10,5 and $1 \%$ significance level respectively. The numbers in parentheses are the corresponding t-statistics of the estimated parameters. D.F. $=$ degrees of freedom

Source: Statistics Austria, various years 
which was in government before and after these four elections, that unemployment has a statistically significant influence on their election outcomes in 2002, 2006 and 2008. Here the growth rate of income has a statistically significant influence, but unfortunately with the "wrong" sign in the last election of 2008. In general we find a declining influence of the growth rate of disposable income.

If one tries to take account of the ceteris paribus condition by including a lagged dependent variable in the estimated functions, the unemployment variable has the theoretically expected sign, but only in the 1999 election is this variable statistically significant. In addition, the growth rate of disposable income is statistically significant and has the theoretically expected sign for all four elections. Here, too, we find a declining influence of this economic variable. In a panel estimation for the People's Party over all four elections, both unemployment and the growth rate of disposable income are statistically significant and have the expected signs. For the other two parties, the influence of the economic variables is mixed and in some cases we obtain the wrong sign.

What conclusions can we draw from these results?

(1) The economic situation does influence the popularity of the three Austrian parties and the election outcomes of these parties at federal level to some extent. However, the results for the popularity functions are mixed and the influence of the economic variables is not robust. In the case of the election/vote functions, the influence of the economic variables for the People's Party, which was in government in these four elections, is somewhat more stable, and except for one case, we have the theoretically predicted sign for the unemployment rate and the growth rate of disposable income.

(2) This instability may be caused by the Austrian political system and by the fact that there were switching coalitions from the 1980s and 1990s to the present day. The time period considered is not long enough to investigate possible economic influences on these different types of coalitions in a thorough way.

(3) Similar to Kirchgässner's results for Germany, it seems that the economic influences on party popularity and election outcomes have been weakening over the last decade. However more thorough investigations are required to confirm this finding.

Acknowledgments Open access funding provided by University of Klagenfurt.

Open Access This article is distributed under the terms of the Creative Commons Attribution 4.0 International License (http://creativecommons.org/licenses/by/4.0/), which permits unrestricted use, distribution, and reproduction in any medium, provided you give appropriate credit to the original author(s) and the source, provide a link to the Creative Commons license, and indicate if changes were made.

\section{References}

Hofreither, M. F. (1988). Popularitätsfunktionen für Österreich, ein simultaner Schätzansatz. Quartalshefte der Girozentrale, 23(1), 75-82. 
Kirchgässner, G. (2009). The lost popularity function: Are unemployment and inflation no longer relevant for the behavior of German voters? CESifo Working Paper No. 2882, Munich.

Lewis-Beck, M. S. (1988). Economics and elections: The major Western democracies. Ann Arbor: University of Michigan Press.

Nannestad, P., \& Paldam, M. (1994). The VP function: a survey of the literature on vote and popularity function after 25 years. Public Choice, 79(2), 213-245.

Neck, R. (1979). Gibt es einen politischen Konjunkturzyklus in Österreich? In C. C. von Weizsäcker (Ed.), Staat und Wirtschaft, Schriften des Vereins für Socialpolitik (pp. 451-472). Berlin: Duncker und Humblot.

Neck, R. (1988). Wahl- und Popularitätsfunktionen für Österreich. Quartalshefte der Girozentrale, 23(1), 4373.

Neck, R. (1996). Der Einfluss der Wirtschaftslage auf die Popularität der politischen Parteien in Österreich. In R. Neck \& F. Schneider (Eds.), Politik und Wirtschaft in den 90er Jahren: Empirische Untersuchungen zur Neuen Politischen Ökonomie (pp. 87-115). Wien: Manz.

Neck, R., \& Karbuz, S. (1995). What remains of the popularity function? The case of Austria. International Advances in Economic Research, 1(3), 263-271.

Neck, R., \& Karbuz, S. (1997). Econometric estimations of popularity functions: a case study for Austria. Public Choice, 91(1), 57-88.

Paldam, M. (1981). A preliminary survey of the theories and findings on vote and popularity functions. European Journal of Political Research, 9(1), 181-199.

Paldam, M. (2004). Are vote and popularity functions economically correct? In C. K. Rowley \& F. Schneider (Eds.), The Encyclopedia of Public Choice (pp. 49-59). Dordrecht: Kluwer.

Sargan, J. D. (1964). Wages and prices in the U.K.: A study in econometric methodology. In P. E. Hart, G. Mills \& J. K. Whitaker. (Eds.), Econometric analysis for national planning (pp. 25-59). London: Butterworth.

Schneider, F., \& Frey, B. S. (1988). Politico-economic models of macro-economic policy: a review of the empirical evidence. In T. D. Willett (Ed.), Political business cycles (pp. 239-275). Durham: Duke University Press.

Statistics Austria, various years, http://www.statistikaustria.at/web_en/statistics/index.html 